\title{
Summer Legumes for Creep Grazing in Cow-Calf Production on Bermudagrass Pastures
}

\author{
W. D. Pitman ${ }^{1}$, Ryon S. Walker ${ }^{1}$, Guillermo Scaglia ${ }^{2}$, Blair Buckley ${ }^{3}$, M. W. Alison ${ }^{4}$, K. J. Han ${ }^{5}$, Jeff Gurie ${ }^{6}$ \\ \& Glen Gentry ${ }^{6}$ \\ ${ }^{1}$ Louisiana State University Agricultural Center, Hill Farm Research Station, Homer, Louisiana, USA \\ ${ }^{2}$ Louisiana State University Agricultural Center, Iberia Research Station, Jeanerette, Louisiana, USA \\ ${ }^{3}$ Louisiana State University Agricultural Center, Red River Research Station, Bossier City, Louisiana, USA \\ ${ }^{4}$ Louisiana State University Agricultural Center, Macon Ridge Research Station, Winnsboro, Louisiana, USA \\ ${ }^{5}$ Louisiana State University Agricultural Center, School of Plant, Soil, and Environmental Sciences, Baton \\ Rouge, Louisiana, USA \\ ${ }^{6}$ Louisiana State University Agricultural Center, Dean Lee Research Station, Alexandria, Louisiana, USA \\ Correspondence: W. D. Pitman, Hill Farm Research Station, 11959 Highway 9, Homer, Louisiana 71040, USA. \\ Tel: 1-318-927-2578. E-mail: wpitman@agcenter.lsu.edu
}

Received: April 21, 2015 Accepted: May 21, 2015 Online Published: July 15, 2015

doi:10.5539/jas.v7n8p8 URL: http://dx.doi.org/10.5539/jas.v7n8p8

\begin{abstract}
The extensive cow-calf industry in the Gulf Coast Region of the southeastern USA is based on pastures of warm-season perennial grasses, which often provide insufficient forage availability and/or nutritive value in late summer. Several species of summer-growing legumes have potential to increase nutrient availability for nursing calves through creep grazing. Selected warm-season legumes were evaluated at multiple locations across Louisiana. At each location, a treatment with $10 \%$ of the pasture area planted to legume was compared to a bermudagrass control treatment. Objectives were to assess both plant and animal factors influencing potential for creep grazing to increase calf weaning weight. Iron-and-Clay cowpea was widely adapted and suited to grazing defoliation although not tolerant of flooding. Aeschynomene was particularly well adapted to silt loam and silty clay loam bottomland soils but was not readily grazed when woody stems developed before stocking. Calves had to learn to utilize creep areas and consume unfamiliar legume species. Both pasture and animal characteristics affected response to legume creep grazing. At the Hill Farm Research Station, the combination of young cows and pastures with limiting nutritive values produced low weaning weights (200 to $215 \mathrm{~kg}$ ) and resulted in weaning weight increases of from 5 to $7 \mathrm{~kg}$ from creep grazing. Benefits were not detected from creep grazing at other locations where calf weaning weights were higher. Creep grazing can contribute to calf weaning weight when forage grazed by the cow herd does not allow calves to attain their genetic potential, however, intensive management is required.
\end{abstract}

Keywords: beef cattle production, forage system, pasture utilization, warm-season legume, weaning weight

\section{Introduction}

Cow-calf production in the Gulf Coast Region of the southeastern USA is primarily based on pastures of warm-season perennial grasses consisting predominately of bermudagrass (Cynodon dactylon [L.] Pers.) or bahiagrass (Paspalum notatum Flugge). Calving is often in late winter or spring with weaning in autumn at the end of the growing season of the warm-season grasses. Weaning weights of calves, averaging only 150 to $200 \mathrm{~kg}$ where management is limited, are often considerably below their genetic potential because of insufficient forage nutritive value or availability (Bagley, 1993). Both unpredictable summer rainfall patterns and inherent growth characteristics of the warm-season perennial pasture grasses contribute to the forage limitations (Pitman, 2007). Providing additional nutrients to nursing calves on pasture as creep-fed concentrate feed has resulted in increased weaning weights, but this has not been consistently cost effective (Stricker et al., 1979; Myers, Faulkner, Ireland, Berger, \& Parrett, 1999). Summer-growing legumes provide potential to enhance forage quality of warm-season perennial grass pastures in the Gulf Coast Region (Thro et al., 1991; Pitman, 2011). Cost-effectiveness of this added forage quality can perhaps be improved by supplying the legume only in creep grazing areas for the calves 
on a portion of the total pasture available.

Such an approach across the region has produced mixed results. Fribourg et al. (1984) reported $41 \%$ greater gain by nursing calves grazing lablab (Lablab purpureus [L.] Sweet) creep forage compared with calves on only common bermudagrass pasture. Williams, Chase, and Hammond (2004) reported an effect of cattle breed on calf response to rhizoma peanut (Arachis glabrata Benth.) creep forage. Romosinuano calves with creep grazing gained $0.14 \mathrm{~kg}$ per day more than did those on the control treatment with no response to creep grazing by Angus calves. Corriher, Hill, Andrae, Froetschel, and Mullinix (2007) obtained an increased average weaning weight of $6.6 \mathrm{~kg}$ for calves with access to an aeschynomene (Aeschynomene americana L.) creep-grazing area compared with calves on only the base bermudagrass pasture. A cowpea (Vigna unguiculata [L.] Walp.) creep-grazing area, which failed to contribute regrowth in July and August, did not increase calf gains on bahiagrass pasture in Florida, even though a creep feeding treatment provided an increase in calf average daily gain of $0.12 \mathrm{~kg}$ (Vendramini, Arthington, \& Adesogan, 2012). At another Florida location, creep feeding provided the highest ADG with creep grazing of either cowpea or rhizoma peanut providing intermediate results between the creep feeding and a control (Foster et al., 2013). Cowpea forage availability, however, became limiting before weaning reducing opportunity for response.

Several summer-growing legumes have been identified as potentially useful pasture species for increasing forage quality of Louisiana pastures on various soil types across the state (Thro et al., 1991). Availability of this high-quality forage source and continued marketing of weaned calves at weights below their genetic potential across the region indicate economic opportunity for the creep grazing approach. Therefore, our objective was to evaluate selected warm-season legumes at multiple locations across Louisiana to assess factors contributing to success of adapted summer-growing legumes for use as creep grazing to improve calf weaning weights.

\section{Materials and Methods}

Legume plantings for evaluation of creep grazing by nursing calves were made in bermudagrass pastures at four research station locations across Louisiana in the spring of 2012 and 2013 . Legume species evaluated differed among locations and years. At the Hill Farm and Red River Research Stations in 2012, legume evaluations consisted of randomized, replicated plantings of Iron-and-Clay cowpea, Quickpick cowpea, aeschynomene, and soybean (Glycine max [L.] Merr.) with alyceclover (Alysicarpus vaginalis [L.] DC) at only the Hill Farm. The 2012 creep area at the Dean Lee Research Station consisted of replicated areas of Iron-and-Clay cowpea and aeschynomene. Creep plantings at all three of these locations in 2013 were of only Iron-and-Clay cowpea. Only alyceclover was planted each year at the Iberia Research Station. At this location, pre-plant grass growth was controlled only by close grazing. At the other three locations, initial spring growth of bermudagrass was suppressed with an application of glyphosate herbicide before legume planting. The area planted to legumes for creep grazing was $10 \%$ of the pasture area available to the cow-calf herd as suggested by Newman, Mayo, and Vendramini (2011). Each creep-grazing treatment was paired with a similarly stocked pasture with no creep forage planting. Pasture size, number of cows per treatment, and number of replications differed among locations and even between years at some locations as shown in Table 1.

Legume growth in the creep plantings and regrowth following grazing were visually monitored with assessments at least twice weekly. Forage nutritive value and herbage availability of legumes in the creep areas were assessed at the dates shown in Tables 2 and 3. Legume herbage availability was determined using either three or five 0.25 $\mathrm{m}^{2}$ samples per experimental unit at each sampling date. Aeschynomene samples at Dean Lee in 2012 were taken from only the upper leafy layer of the legume canopy. Measures of forage nutritive value included NDF and ADF according to procedures of Robertson and Van Soest (1981), in vitro true digestibility (IVTD) using procedures of Goering and Van Soest (1970), and crude protein (CP) using the semimicro-Kjeldahl procedure of Bremmer and Breitenbeck (1983). At the Hill Farm Research Station in 2012, two legume species which were closely grazed with no indication of regrowth were further evaluated using three 1.5 by $1.5 \mathrm{~m}$ exclosure cages per pasture treatment replication. Legume growth present within cages after four weeks was clipped, dried, weighed to determine regrowth dry matter, and analyzed for forage nutritive value as described above. Iron-and-Clay cowpea at the Hill Farm was sampled on August 30, 2013 with three samples from each creep pasture collected, separated into leaf and stem components, weighed for determination of leaf and stem dry matter proportions, and analyzed for measures of forage nutritive value as described above. Bermudagrass available in pasture areas grazed by the cow herds was visually monitored on a weekly basis and sampled at the dates shown in Table 4. Available forage was determined from three $9 \mathrm{~m}^{2}$ samples per experimental unit at each sampling date. Forage nutritive value was determined from subsamples of each pasture sample using the procedures noted above for the nutritive value assessment of legume samples. 
Table 1. Pastures and cow-calf pairs in legume creep grazing evaluations at four Louisiana locations

\begin{tabular}{lllllll}
\hline Location & Year & Soil texture & $\begin{array}{l}\text { Total pasture } \\
\text { area (ha) }\end{array}$ & $\begin{array}{l}\text { Total number of } \\
\text { cow-calf pairs }\end{array}$ & $\begin{array}{l}\text { Treatment } \\
\text { replications }\end{array}$ & $\begin{array}{l}\text { Legume planting } \\
\text { date }\end{array}$ \\
\hline Red River & 2012 & Clay & 12 & 30 & 2 & May 15-16 \\
Red River & 2013 & Clay & 12 & 18 & 2 & May 16 \\
Hill Farm & 2012 & Fine sand/fine sandy loam & 24 & 44 & 3 & June 15-16 \\
Hill Farm & 2013 & Fine sand/fine sandy loam & 24 & 44 & 3 & May 2 \\
Dean Lee & 2012 & Silt loam/silty clay loam & 32 & 41 & 2 & April 25-26 \\
Dean Lee & 2013 & Silt loam/silty clay loam & 25 & 38 & 3 & April 25 \\
Iberia & 2012 & Silty clay loam & 26 & 43 & 2 & June 4 \\
Iberia & 2013 & Silty clay loam & 26 & 43 & 2 & June 12 \\
\hline
\end{tabular}

Pastures were stocked with crossbred cows of predominately Angus breeding and their spring-born nursing calves. Treatment groups for the creep grazing evaluation were smaller than the breeding herds managed at each research station requiring delay of creep grazing evaluations until the end of the breeding season for distribution of cow-calf pairs to the experimental units. Creep grazing evaluations occurred during the period from late June until weaning in October, although length of each individual grazing period (listed in Table 5) was determined by forage availability within this time period. Calf weights at the start and end of each grazing period were used to calculate calf body weight gain and calf average daily gain (ADG) during the period of access to the creep forage Initial response of calves to availability of the legume forage was monitored on a daily basis. Use of the creep areas, which were separated from the base pastures by electric fence with creep access openings as described by Newman et al. (2011), was encouraged initially by location of the plantings and access openings near water, shade, and minerals. Additional approaches to introduce calves to the creep forage included moving minerals inside the creep area, raising the bottom electric-fence wire to allow calf access beneath the full length of the electric fence, and eventually providing short-term access to the creep plantings for both cows and calves.

Plant growth responses from each individual sampling date were subjected to analysis of variance using Proc ANOVA in SAS (SAS Institute Inc., Cary, NC, USA) with legume species, replication, and sample within replication as fixed effects for the plant responses forage mass, NDF, ADF, IVTD, and CP. Calf body weight gain and ADG were analyzed using Proc GLM of SAS with a combined model for both years and the three locations which had pure legume stands (Dean Lee, Hill Farm, and Red River). In the combined model, individual animal was considered the experimental unit to allow assessment of effects of cow age and calf sex. The model included the treatment (creep vs. control), replication, year, location, cow age, and calf sex with all two-way interactions. Subsequent evaluation of this combined data set using Proc GLM included a first order autoregressive covariance structure with dam age and calf sex as covariates. Because of interactions and legume treatment differences in years and locations, GLM models with treatment, replication, and their interaction within each of the eight experimental periods (locations and years) were also assessed for the responses calf body weight gain and ADG. For the individual grazing-period evaluations, pasture was considered the experimental unit.

\section{Results}

Location effects, rather than legume species, provided the major difference in legume stand development in 2012. Soil moisture at Dean Lee was favorable and legume stands provided sufficient forage for grazing several weeks before treatments could be started. At both the Hill Farm and Red River, soil moisture limitations delayed emergence and early growth of all legume species. The period of limited soil moisture was more severe and lasted somewhat longer at the Red River location. 
Table 2. Legume forage characteristics of creep grazed plantings

\begin{tabular}{|c|c|c|c|c|c|c|c|}
\hline Location & Date & Legume & $\begin{array}{l}\text { Forage mass } \\
\left(\mathrm{kg} \mathrm{ha}^{-1}\right)\end{array}$ & $\operatorname{NDF}\left(\mathrm{g} \mathrm{kg}^{-1}\right)$ & $\mathrm{ADF}\left(\mathrm{g} \mathrm{kg}^{-1}\right)$ & $\operatorname{IVTD}\left(\mathrm{g} \mathrm{kg}^{-1}\right)$ & $\mathrm{CP}\left(\mathrm{g} \mathrm{kg}^{-1}\right)$ \\
\hline Dean Lee & July 3,2012 & Iron-and-Clay cowpea & 2135 & 341 & 243 & 885 & 179 \\
\hline \multirow[t]{2}{*}{ Dean Lee } & July 3,2012 & Aeschynomene & & 405 & 219 & 868 & 182 \\
\hline & & $P$-value & & 0.0018 & 0.08 & 0.14 & 0.82 \\
\hline Dean Lee & Sept. 6, 2012 & Iron-and-Clay cowpea & 3035 & 469 & 348 & 794 & 186 \\
\hline \multirow[t]{2}{*}{ Dean Lee } & Sept. 6, 2012 & Aeschynomene & 3371 & 624 & 424 & 689 & 156 \\
\hline & & $P$-value & 0.76 & 0.0024 & 0.024 & 0.0009 & 0.05 \\
\hline Hill Farm & July 25, 2012 & Iron-and-Clay cowpea & $6469 \mathrm{a}^{1}$ & $384 \mathrm{a}$ & 248 & $857 \mathrm{~b}$ & 258 \\
\hline Hill Farm & July 25, 2012 & Soybean & $4041 \mathrm{~b}$ & $371 \mathrm{ab}$ & 238 & $854 \mathrm{~b}$ & 270 \\
\hline \multirow[t]{2}{*}{ Hill Farm } & July 25, 2012 & Quickpick cowpea & $5531 \mathrm{ab}$ & $337 \mathrm{~b}$ & 231 & $885 \mathrm{a}$ & 274 \\
\hline & & $P$-value & 0.0148 & 0.0312 & 0.5823 & 0.0129 & 0.6942 \\
\hline Hill Farm & Sept. 12, 2012 & Soybean & 2160 & 423 & 308 & 747 & 188 \\
\hline \multirow[t]{2}{*}{ Hill Farm } & Sept. 12, 2012 & Alyceclover & 1000 & 436 & 294 & 803 & 218 \\
\hline & & $P$-value & 0.0001 & 0.8643 & 0.8158 & 0.0209 & 0.0309 \\
\hline Hill Farm & Oct. 15,2012 & Iron-and-Clay cowpea & 733 & 543 & 408 & 713 & 163 \\
\hline \multirow[t]{2}{*}{ Hill Farm } & Oct. 15,2012 & Aeschynomene & & 415 & 267 & 817 & 217 \\
\hline & & $P$-value & & 0.0024 & 0.0005 & 0.0078 & 0.0296 \\
\hline Red River & Aug. 28, 2012 & Iron-and-Clay cowpea & & $322 \mathrm{c}$ & $225 \mathrm{c}$ & $884 \mathrm{a}$ & $182 \mathrm{~b}$ \\
\hline Red River & Aug. 28, 2012 & Aeschynomene & & $368 \mathrm{ab}$ & $269 \mathrm{ab}$ & $864 \mathrm{a}$ & $215 \mathrm{a}$ \\
\hline Red River & Aug. 28, 2012 & Soybean & & $341 \mathrm{bc}$ & $240 \mathrm{bc}$ & $876 \mathrm{a}$ & $187 \mathrm{~b}$ \\
\hline \multirow[t]{2}{*}{ Red River } & Aug. 28, 2012 & Quickpick cowpea & & $403 \mathrm{a}$ & $287 \mathrm{a}$ & $816 \mathrm{~b}$ & $172 \mathrm{~b}$ \\
\hline & & $P$-value & & 0.0017 & 0.0069 & 0.0002 & 0.0263 \\
\hline
\end{tabular}

Note. ${ }^{1}$ Means within a column for a common location and date do not differ $(P>0.05)$ when followed by a common letter.

Aeschynomene stands were rather sparse at the Hill Farm compared to the other legumes at that location and aeschynomene stands at Dean Lee. Grass suppression with glyphosate allowed legume stands to establish without substantial competition from bermudagrass but perhaps facilitated broadleaf weed competition. At the Hill Farm and Red River, pigweed (Amaranthus sp.) provided competition to legumes in both years, while at Dean Lee, weed competition was substantial only in 2013 with ragweed (Ambrosia sp.) providing the primary competition. Despite the weed component, opportunity for calves to select only legume forage was provided in creep areas at the Red River, Hill Farm, and Dean Lee Research Stations. At the Iberia Research Station, where bermudagrass growth was not suppressed with herbicide, the alyceclover stand developed within the bermudagrass canopy providing a mixed grass-legume creep forage. In contrast to the limited soil moisture at the Red River location in 2012, rainfall in the 2013 growing season resulted in periodic flooded conditions in portions of the creep areas at the Red River location and in one of the three creep replications at Dean Lee. Cowpea did not survive in the portions of the creep areas where extended flooding occurred.

Calves did not initially utilize the creep areas, and even after entering the areas, they did not immediately graze the legume forage. After a week of access by only the calves, both cows and calves were allowed access to the creep areas for an hour or two daily for two to four days with this process repeated over an additional two weeks at Dean Lee in 2012. Even the cows initially grazed small areas of weedy grasses and sometimes the pigweed before consuming any legume forage. At Dean Lee in 2012, cattle utilized only the weedy grasses along the edges of the tall legume creep forage before gradually moving into cowpea areas and consuming upper leaves of the cowpea after almost three weeks of periodic access by the cow herd. The aeschynomene forage at this location was essentially un-utilized during the creep grazing period. At the Hill Farm, cows and subsequently calves grazed alyceclover and soybean to within 2 to $3 \mathrm{~cm}$ of the soil surface before grazing the other legumes. All legumes at this location and the Red River location provided primarily leaf and succulent stem growth, which was grazed and maintained in a succulent vegetative growth stage. 
Table 3. Forage mass and nutritive value of Iron-and-Clay cowpea in creep grazed treatments

\begin{tabular}{|c|c|c|c|c|c|c|c|}
\hline Location & Date & Component & Forage mass $\left(\mathrm{kg} \mathrm{ha}^{-1}\right)$ & $\mathrm{NDF}\left(\mathrm{g} \mathrm{kg}^{-1}\right)$ & $\mathrm{ADF}\left(\mathrm{g} \mathrm{kg}^{-1}\right)$ & $\operatorname{IVTD}\left(\mathrm{g} \mathrm{kg}^{-1}\right)$ & $\mathrm{CP}\left(\mathrm{g} \mathrm{kg}^{-1}\right)$ \\
\hline Dean Lee & July 3,2012 & Whole plant & $2135 b^{1}$ & 341 & 243 & 885 & 179 \\
\hline Dean Lee & Sept. 6, 2012 & Whole plant & $3035 \mathrm{~b}$ & 469 & 348 & 794 & 186 \\
\hline Red River & Aug. 28, 2012 & Whole plant & $3306 \mathrm{~b}$ & 322 & 225 & 884 & 182 \\
\hline Hill Farm & July 25,2012 & Whole plant & $6491 \mathrm{a}$ & 384 & 248 & 857 & 258 \\
\hline Hill Farm & Oct. 15,2012 & Whole plant & $733 \mathrm{c}$ & 543 & 408 & 713 & 163 \\
\hline Hill Farm & June 28, 2013 & Whole plant & $3665 \mathrm{~b}$ & 439 & 338 & 824 & 167 \\
\hline Hill Farm & Aug. 30, 2013 & Leaf $^{2}$ & & 254 & 148 & 938 & 227 \\
\hline \multirow[t]{2}{*}{ Hill Farm } & Aug. 30, 2013 & Stem $^{2}$ & & 652 & 513 & 669 & 64 \\
\hline & & $P$-value ${ }^{3}$ & & 0.0001 & 0.0001 & 0.0001 & 0.0001 \\
\hline
\end{tabular}

Note. ${ }^{1}$ Means within a column do not differ $(P>0.05)$ when followed by a common letter; ${ }^{2}$ Leaves were $6 \%$ and stems were $94 \%$ of cowpea samples from the August 30, 2013 sampling at the Hill Farm; ${ }^{3}$ Probability of difference between leaf and stem samples at the Hill Farm on August 30, 2013.

At Dean Lee in 2012, both the cowpea and aeschynomene attained heights exceeding $1 \mathrm{~m}$ with considerable stem development before any legume herbage was consumed by either the cows or calves. Even though the lower canopy of aeschynomene was primarily woody stems, the upper canopy provided succulent leafy growth of high nutritive value particularly at the July 3, 2012 sampling date (Table 2). Aeschynomene at the Hill Farm and Red River Stations was grazed before woody stem development occurred and was repeatedly re-grazed to maintain succulent regrowth as were the other legumes. When sufficient aeschynomene was available to sample at these locations, the aeschynomene forage was considerably higher $(P<0.05)$ in $\mathrm{CP}$ than were the other legumes (Table 2).

Table 4. Forage nutritive value of bermudagrass pastures available to cow herds and mixed alyceclover-bermudagrass available to calves for creep grazing at the Iberia Research Station

\begin{tabular}{|c|c|c|c|c|c|c|}
\hline Treatment & Component & Forage & Date & $\mathrm{NDF}\left(\mathrm{g} \mathrm{kg}^{-1}\right)$ & $\mathrm{ADF}\left(\mathrm{g} \mathrm{kg}^{-1}\right)$ & $\mathrm{CP}\left(\mathrm{g} \mathrm{kg}^{-1}\right)$ \\
\hline Creep grazing & Calf creep & Alyceclover-bermudagrass mixture & June 4, 2012 & $672 b^{1}$ & $401 \mathrm{a}$ & $196 \mathrm{a}$ \\
\hline Creep grazing & Cow-herd pasture & Bermudagrass & June 4, 2012 & $795 \mathrm{a}$ & $467 \mathrm{a}$ & $118 \mathrm{~b}$ \\
\hline Control & & Bermudagrass & June 4, 2012 & $802 \mathrm{a}$ & $448 \mathrm{a}$ & $143 \mathrm{~b}$ \\
\hline Creep grazing & Calf creep & Alyceclover-bermudagrass mixture & July 14,2012 & $695 \mathrm{~b}$ & $416 \mathrm{~b}$ & $175 \mathrm{a}$ \\
\hline Creep grazing & Cow-herd pasture & Bermudagrass & July 14,2012 & 802 a & $482 \mathrm{a}$ & $133 \mathrm{~b}$ \\
\hline Control & & Bermudagrass & July14, 2012 & $836 \mathrm{a}$ & $527 \mathrm{a}$ & $81 \mathrm{c}$ \\
\hline Creep grazing & Calf creep & Alyceclover- bermudagrass mixture & June 12,2013 & $682 \mathrm{~b}$ & $376 b$ & $218 \mathrm{a}$ \\
\hline Creep grazing & Cow-herd pasture & Bermudagrass & June 12, 2013 & $813 \mathrm{a}$ & $453 \mathrm{a}$ & $140 \mathrm{~b}$ \\
\hline Control & & Bermudagrass & June 12, 2013 & $815 \mathrm{a}$ & 509 a & $119 \mathrm{~b}$ \\
\hline Creep grazing & Calf creep & Alyceclover-bermudagrass mixture & July 22, 2013 & $768 \mathrm{a}$ & $468 \mathrm{~b}$ & $124 \mathrm{a}$ \\
\hline Creep grazing & Cow-herd pasture & Bermudagrass & July 22,2013 & $821 \mathrm{a}$ & $510 \mathrm{a}$ & $119 \mathrm{a}$ \\
\hline Control & & Bermudagrass & July 22, 2013 & $830 \mathrm{a}$ & $512 \mathrm{a}$ & $105 \mathrm{a}$ \\
\hline
\end{tabular}

Note. ${ }^{1}$ Means in a column within each date do not differ $(P>0.05)$ when followed by a common letter.

At the Hill Farm, the aggressive selective grazing of the replicated areas of alyceclover and soybean suggested lack of regrowth from these two species. Grazing exculsion with cages verified regrowth capability of both species with the soybean producing twice as much regrowth as the alyceclover $(P<0.01)$ following the extended period of very close, repeated grazing (Table 2, September 12, 2012 sampling). Under rather intensive grazing pressure at both the Red River and Hill Farm locations, individual plants of aeschynomene, soybean, and Quickpick cowpea were considerably less vigorous than were plants of Iron-and-Clay cowpea. Quickpick 
cowpea flowered and produced a few pods indicating partitioning of photosynthate to reproductive growth even under the intense grazing defoliation. Although differences in some responses were obtained at some dates, all of the legumes produced forage of high nutritive value (Table 2). At the three locations where the creep plantings consisted of only Iron-and-Clay cowpea in 2013, grazing pressure was sufficient to limit available leaf material, and selective grazing of leaves gradually produced cowpea plants with stemmy bases and small proportions of leaf material. Table 3 shows the range in nutritive value of the Iron-and-Clay cowpea across locations and years and illustrates the late season differences in leaf and stem components (Hill Farm sampling on August 30, 2013). Mature Iron-and-Clay cowpea stem, in contrast to the cowpea leaf and even previously sampled mixtures of cowpea leaves and succulent stems, did not provide forage nutritive values superior to the bermudagrass pastures.

The alyceclover creep planting at Iberia provided early season forage quality superior $(P<0.05)$ to that of the base bermudagrass pasture (Table 4), even though the legume was not a pure stand. As illustrated by the July 2013 data (Table 4) late-season forage in the creep areas did not maintain the early season nutritive value benefit as bermdagrass growth dominated creep areas in late summer.

Table 5. Forage available for cow herds with and without creep grazing areas for calves

\begin{tabular}{llllllll}
\hline Treatment & Location & Date & Forage mass $\left(\mathrm{kg} \mathrm{ha}^{-1}\right)$ & $\mathrm{NDF}\left(\mathrm{g} \mathrm{kg}^{-1}\right)$ & $\mathrm{ADF}\left(\mathrm{g} \mathrm{kg}^{-1}\right)$ & $\mathrm{IVTD}_{\left(\mathrm{g} \mathrm{kg}^{-1}\right)}$ & $\mathrm{CP}\left(\mathrm{g} \mathrm{kg}^{-1}\right)$ \\
\hline Creep & Dean Lee & Sept. 6, 2012 & 682 & 702 & 366 & 625 & 90 \\
Control & Dean Lee & Sept. 6, 2012 & 1807 & 683 & 317 & 642 & 101 \\
& & $P$-value & 0.04 & 0.29 & 0.20 & 0.44 & 0.49 \\
Creep & Dean Lee & Aug. 27, 2013 & 1397 & 667 & 315 & 685 & 102 \\
Control & Dean Lee & Aug. 27, 2013 & 1851 & 657 & 296 & 686 & 114 \\
& & $P$-value & 0.33 & 0.51 & 0.27 & 0.96 & 0.09 \\
Creep & Hill Farm & Aug. 14, 2012 & 1168 & 702 & 321 & 703 & 117 \\
Control & Hill Farm & Aug. 14 2012 & 1222 & 710 & 321 & 699 & 116 \\
& & $P$-value & 0.89 & 0.30 & 0.10 & 0.71 & 0.77 \\
Creep & Hill Farm & Aug. 26, 2013 & 1252 & 718 & 322 & 663 & 87 \\
Control & Hill Farm & Aug. 26, 2013 & 1604 & 716 & 324 & 594 & 82 \\
& & $P$-value & 0.29 & 0.90 & 0.93 & 0.20 & 0.58 \\
\hline
\end{tabular}

Forage availability in the base bermudagrass pasture portion of the creep grazing treatment was substantially less $(P=0.04)$ than that of the control treatment at Dean Lee at the September 6, 2012 sampling (Table 5). This difference was visually discernable during the last six weeks of the 2012 grazing period with no other measured or visually detectable differences in bermudagrass availability between treatments. Measures of forage nutritive value in late summer, when pasture quality often limits animal gains, were somewhat variable among locations and years particularly for CP (Table 5). The only difference between the creep grazing and control treatment base bermudagrass pasture samples for any measure of forage nutritive value was lower $(P<0.05) \mathrm{CP}$ of the control than the pastures with creep grazing at Iberia in July 2012 (Tables 4 and 5).

Within individual locations and years, calf body weight gain from access to legume creep grazing occurred only at the Hill Farm (Table 6). Combined analysis of calf gains from the pure legume creep treatments, which provided assessment of a broader range of experimental variables, revealed year by location interactions $(P<$ $0.05)$ and effects $(P<0.05)$ of calf sex and cow age on calf body weight gain. Analyzing this combined data set with cow age and calf sex as covariates indicated greater $(P=0.01)$ gain per calf (with an average of $5 \mathrm{~kg}$ more) from the creep treatment than from the control (Table 6). Despite substantial differences in length of the creep grazing period among locations and years, average daily gain responses to creep grazing were very similar to those for total gain. Average daily gains from the creep and control treatments ranged from lows of 0.67 and 0.58 $\mathrm{kg}$ at the Hill Farm in 2012 to 1.23 and $1.19 \mathrm{~kg}$ at Dean Lee in 2013. Calf ADG was also high at Dean Lee in 2012 , which was the only period when bermudagrass forage availability was detectably lower for cows in the creep treatment than for the control (Table 5). No detrimental effect was obtained on calf gain in the creep treatment, despite the reduced forage availability for the cow herd, with ADG of 1.12 vs. 1.10 for the control. Average weaning weights ranged from $200 \mathrm{~kg}$ at the Hill Farm in 2013 to $297 \mathrm{~kg}$ at Dean Lee in 2013. Cows represented a range of ages of mostly mature cows at most locations. In contrast, cows at the Hill Farm in 2012, 
when weaning weights averaged $215 \mathrm{~kg}$, had calved as two-year olds and were nursing their first calf. Cows at this location in 2013 were nursing either their first or second calf with average weaning weights of $200 \mathrm{~kg}$. Thus the effect of cow age on calf body weight gain detected for the combined data set corresponds with the lower weaning weights of calves from young cows at the Hill Farm where calves responded to the creep forage.

Table 6. Grazing periods and body weight gains of nursing calves from summer legume creep grazing

\begin{tabular}{lllllll}
\hline \multirow{2}{*}{ Location } & Year & Starting date & Length of grazing period (days) & \multicolumn{3}{c}{ Calf body weight gain (kg) } \\
\cline { 5 - 7 } & & & & Creep & Control & $P$-value \\
\hline Red River & 2012 & Aug. 23 & 60 & 66 & 63 & 0.26 \\
Red River & 2013 & July 2 & 99 & 84 & 81 & 0.57 \\
Hill Farm & 2012 & July 24 & 82 & 65 & 60 & 0.03 \\
Hill Farm & 2013 & July 27 & $103(70)^{1}$ & 55 & 48 & 0.08 \\
Dean Lee & 2012 & July 2 & 96 & 107 & 105 & 0.61 \\
Dean Lee & 2013 & June 20 & 109 & 134 & 130 & 0.28 \\
Iberia & 2012 & July 16 & 83 & 58 & 60 & 0.55 \\
Iberia & 2013 & July 23 & 76 & 73 & 70 & 0.59 \\
Combined & Both & & & 85 & 80 & 0.01
\end{tabular}

Note. ${ }^{1}$ At the Hill Farm in 2013, one of the three replications of both treatments was terminated early (September 5 ) because of limited forage in the creep area for that replication; ${ }^{2}$ The combined data set does not include results from Iberia, where the creep forage was a grass-legume mixture rather than only legume.

\section{Discussion}

Legume growth in the creep plantings was somewhat similar to results presented by Thro et al. (1991), who reported variable yields of summer-growing legumes from year to year at a range of Louisiana locations. They reported suitability of cowpea for sandy soils, while we obtained continuing growth of cowpea on both sandy and heavier soils with good drainage but not where flooded. Thro et al. (1991) suggested that aeschynomene was specifically adapted to alluvial soils but not to sandy soils, which concurs with our results of impressive aeschynomene growth on silty loam and silty clay loam soils at Dean Lee and poor stands on sandy upland soil at the Hill Farm. Wide adaptation was recognized by Thro et al. (1991) for alyceclover, even though establishment limitations were reported for this species in response to consecutive spring planting seasons with an excessively wet spring followed by a very dry spring at Baton Rouge. They reported adaptation of both aeschynomene and alyceclover to a site at the Iberia Research Station and noted the palatability of alyceclover, which we also observed. Common annual alyceclover, which is the variety planted at Iberia and the Hill Farm, is recognized as an erect growing variety, although prostrate growing types of alyceclover are recognized as a distinct separate phenological type (Kretschmer \& Pitman, 1995). The heavily grazed alyceclover stand at the Hill Farm in 2012 produced low-growing persistent plants similar in growth form to prostrate types suggesting considerable phenotypic plasticity in response to severe defoliation in the genotype planted. Such variation expressed in plant growth in response to herbivory is noted as a major source of plant phenotype plasticity (Callaway, Pennings, \& Richards, 2003). The limited, decumbent regrowth of heavily grazed alyceclover at the Hill Farm is consistent with the recognized lower productivity of prostrate growing alyceclover types compared to erect growing types (Kretschmer \& Pitman, 1995). Such plant plasticity can allow plant survival and continued, although reduced, forage production providing considerable grazing tolerance to alyceclover.

Our measures of forage nutritive value of the legumes, which were consistently superior to those of the base bermudagrass pastures, are similar to those reported for warm-season forage legumes by Fribourg et al. (1984), Williams et al. (2004), Corriher et al. (2007), and Vendramini et al. (2012) in previous evaluations of creep grazing. Development of woody, poorly digestible, unpalatable stem growth by aeschynomene through the growing season despite highly digestible and palatable early season growth in Florida pasture evaluations (Aiken, Pitman, Chambliss, \& Portier, 1991a, 1991b), reflects the acceptability by our calves of succulent aeschynomene growth at the Hill Farm and Red River locations contrasted with lack of acceptance of more mature aeschynomene at Dean Lee. Potential of aeschynomene to contribute to animal production even as a low 
proportion of available forage is illustrated by ADG of 1.70 and $1.46 \mathrm{~kg}$ by yearling steers on bahiagrass pastures with 12 and 6\%, respectively, of herbage dry matter from the legume compared to ADG of from 0.79 to $0.84 \mathrm{~kg}$ with no legume (Pitman, Portier, Chambliss, \& Kretschmer, 1992). Thus the lack of acceptance of aeschynomene and lack of creep gain response with substantial available leafy aeschynomene in the upper canopy does not indicate lack of forage nutritive value of aeschynomene but rather calf reluctance to accept the unfamiliar forage. The potential of aeschynomene as a creep grazing forage is verified by the $6.6 \mathrm{~kg}$ higher weaning weight for creep-grazed calves reported by Corriher et al. (2007). Adequate availability of acceptable high-quality forage in a creep grazing area can enhance calf gains as indicated by increased weaning weights of calves from a forage system with greater creep forage availability than from similar systems with limited availability of creep forage (Scaglia et al., 2008). This suggests that increasingly limiting quantities of legume leaf, which occurred during most of our grazing periods, likely limited legume intake and calf response to creep grazing in at least some instances.

Opportunity for optimal response from creep grazing was not provided in any of the grazing periods in this evaluation. Because the adapted, high-quality legumes have potential to provide forage from May until the typical October weaning date under Louisiana conditions, an optimal creep grazing period for this environment should approach 150 days in length. Creep feeding periods extending over the last 28,56 , and 84 days before weaning increased calf ADG by $0.145,0.330$, and $0.495 \mathrm{~kg}$, respectively, on endophyte-infected tall fescue (Festuca arundinacea Schreb.) pasture (Tarr et al., 1994), indicating potential for an extended creep period. Summer annual legumes can be planted in April in Louisiana when soil moisture conditions are generally favorable for stand establishment. Calves should be introduced to creep grazing early in the season before tall, stemmy legume growth is produced as illustrated by the lack of aeschynomene grazing at Dean Lee in 2012. The requirement for calf adaptation to creep forage is similar to response to creep feed reported by Stricker et al. (1979) where calves failed to learn to eat creep feed in one of four years of evaluation. Both the cows and pastures provided substantial effects on benefits obtained from creep grazing. Mature cows have substantial buffering capacity on calf performance, especially cows with high potential for milk production. Cows which calve as two-year olds and are nursing their first calf have continuing nutrient requirements for growth and limited capacity to buffer calf performance. This cow effect undoubtedly contributed to the significant $(P=0.03)$ creep-grazing response of $5 \mathrm{~kg}$ per calf at the Hill Farm in 2012 when all cows at this location had calved as two-year olds and were nursing their first calf. Pasture quality affects both milk production and forage nutrients available for calf consumption. Our largest increase in gain from creep grazing of $7 \mathrm{~kg}$ per calf was obtained when base-pasture bermudagrass nutritive value, particularly CP, was distinctly low at the Hill Farm in 2013 and the cow herd consisted of young cows with their first or second calf.

From our results, several factors can apparently contribute to opportunity for success of legume creep grazing. The best legume stands, even though they were not effectively utilized, resulted from April plantings and other plantings were later with several sustaining some degree of stand reduction from soil moisture limitation. Calves required time and some inducement to access creep areas and accept unfamiliar legume forage. Opportunity for calf gain from creep forage was, at least to some extent, related to low nutritive content of forage in the base pasture. Calves nursing young cows had potential to respond to high quality creep forage. Iron-and-Clay cowpea was adapted to a range of Louisiana sites not subjected to flooding and produced continuing regrowth through the growing season. Grazing management to provide regrowth of this legume throughout the summer may require increasing the size of the creep grazing planting or rotational stocking of the creep area. Aeschynomene was highly productive on a moist silt loam soil but produced stemmy growth not readily grazed following delayed stocking. Creep grazing is a management practice with potential usefulness under specific pasture and animal conditions requiring rather intensive management and a learning period by both grazing calves and managers.

\section{References}

Aiken, G. E., Pitman, W. D., Chambliss, C. G., \& Portier, K. M. (1991a). Responses of yearling steers to different stocking rates on a subtropical grass-legume pasture. Journal of Animal Science, 69, 3348-3356. http://dx.doi.org/1991.6983348x

Aiken, G. E., Pitman, W. D., Chambliss, C. G., \& Portier, K. M. (1991b). Plant responses to stocking rate on a $\begin{array}{lllll}\text { subtropical grass-legume } & \text { pasture. Agronomy Journal, } & \text { 83, }\end{array}$ http://dx.doi.org/10.2134/agronj1991.00021962008300010029x

Bagley, C. P. (1993). Nutritional management of replacement beef heifers: A review. Journal of Animal Science, 71(11), 3155-3163. http://dx.doi.org/1993.71113155x 
Bremmer, J. M., \& Breitenbeck, G. A. (1983). A simple method for determination of ammonium in semimicro-Kjeldahl analysis of soils and plant materials using a block digester. Communications in Soil Science and Plant Analysis, 14, 905-913. http://dx.doi.org/10.1080/00103628309367418

Callaway, R. M., Pennings, S. C., \& Richards, C. L. (2003). Phenotypic plasticity and interactions among plants. Ecology, 84, 1115-1128. http://dx.doi.org/10.1890/0012-9658\%282003\%29084\%5B1115\%3APPAIAP\%5D $2.0 \mathrm{CO} \% 3 \mathrm{~B} 2$

Corriher, V. A., Hill, G. M., Andrae, J. G., Froetschel, M. A., \& Mullinix, B. G. Jr. (2007). Cow and calf performance on Coastal or Tifton 85 bermudagrass pastures with aeschynomene creep-grazing paddocks. Journal of Animal Science, 85, 2762-2771. http://dx.doi.org/10.2527/jas.2007-0015

Foster, J. L., Carter, J. N., Lamb, G. C., Sollenberger, L. E., Blount, A. R., Myer, R. O., ... Adesogan, A. T. (2013). Performance of beef cattle creep fed concentrate or creep grazed on warm-season legumes. Crop Science, 53, 1818-1825. http://dx.doi.org/10.2135/cropsci2012.11.0648

Fribourg, H. A., Overton, J. R., McNeill, W. W., Culvahouse, E. W., Montgomery, M. J., Smith, M., ... Robinson, N. W. (1984). Evaluations of the potential of hyacinth bean as an annual warm-season forage in the $\begin{array}{llll}\text { mid-South. } & \text { Agronomy } & \text { Journal, } & \text { 905-910. }\end{array}$ http://dx.doi.org/10.2134/agronj1984.00021962007600060011x

Goering, H. K., \& Van Soest, P. J. (1970). Forage fiber analyses (apparatus, reagents, procedures, and some applications). Agricultural Handbook (No. 379). Washington, DC: U.S. Department of Agriculture, Agricultural Research Service.

Kretschmer, A. E. Jr., \& Pitman, W. D. (1995). Tropical and subtropical forages. In R. F. Barnes, D. A. Miller, \& C. J. Nelson (Eds.), Forages: Vol. I. An introduction to grassland agriculture (5th ed., pp. 283-304). Ames, Iowa: Iowa State University Press.

Myers, S. E., Faulkner, D. B., Ireland, F. A., Berger, L. L., \& Parrett, D. F. (1999). Production systems comparing early weaning to normal weaning with or without creep feeding for beef steers. Journal of Animal Science, 77, 300-310. http://dx.doi.org/1999.772300x

Newman, Y. C., Mayo, D. E., \& Vendramini, J. (2011). Creep grazing for suckling calves, a pasture management practice. IFAS Extension Publication SS-AGR-211. Gainesville, FL: University of Florida, Institute of Food and Agricultural Science.

Pitman, W. D. (2007). Forage systems for warm humid areas. In R. F. Barnes, C. J. Nelson, K. J. Moore, \& M. Collins (Eds.), Forages: Vol. II. The science of grassland agriculture (6th ed., pp. 303-311). Oxford, UK: Blackwell Publishing.

Pitman, W. D. (2011). Pastures of the U.S. Western Gulf Coast Region. In N. T. Prochazka (Ed.), Pastures: dynamics, economics and management (pp. 85-107). New York: Nova Science Publishers.

Pitman, W. D., Portier, K. M., Chambilss, C. G., \& Kretschmer, A. E. Jr. (1992). Performance of yearling steers grazing bahia grass pastures with summer annual legumes or nitrogen fertilizer in subtropical Florida. $\begin{array}{lllll}\text { Tropical Grasslands, } & 26, & \text { 206-211. } & \text { Retrieved }\end{array}$ http://tropicalgrasslands.info/index.php/tgft/pages/view/tropicalGrasslands

Robertson, J. B., \& Van Soest, P. J. (1981). The detergent system of analysis and its application to human foods. In W. P. T. James \& O. Theander (Eds.), The analysis of dietary fiber (pp. 123-158). New York: Marcell Dekker.

Scaglia, G., Swecker, W. S. Jr., Fontenot, J. P., Fiske, D., Fike, J. H., Obaye, A. O., ... Hall, J. B. (2008). Forage systems for cow-calf production in the Appalachian region. Journal of Animal Science, 86, 2032-2042. http://dx.doi.org/10.2527/jas.2007-0407

Stricker, J. A., Matches, A. G., Thompson, G. B., Jacobs, V. E., Martz, F. A., Wheaton, H. N., ... Krause, G. F. (1979). Cow-calf production on tall fescue-ladino clover pastures with and without nitrogen fertilization or creep feeding: Spring calves. Journal of Animal Science, 48, 13-25. http://dx.doi.org/10.2134/jas1979.48113x

Tarr, S. L., Faulkner, D. B., Buskirk, D. D., Ireland, F. A., Parrett, D. F., \& Berger, L. L. (1994). The value of creep feeding during the last 84,56 , and 28 days prior to weaning on growth performance of nursing calves grazing endophyte-infected tall fescue. Journal of Animal Science, 72, 1084-1094. http://dx.doi.org/1994.7251084x 
Thro, A. M., Mooso, G. D., Friesner, D. L., Gates, R. N., Morris, D. R., Joost, R. E., ... Mitchell, R. L. (1991). Adaptation and yield of summer pasture legumes in Louisiana. Bulletin No. 825. Baton Rouge, LA: Louisiana Agricultural Experiment Station.

Vendramini, J. M. B., Arthington, J. D., \& Adesogan, A. T. (2012). Effects of incorporating cowpea in a subtropical grass pasture on forage production and quality and the performance of cows and calves. Grass and Forage Science, 67, 129-135. http://dx.doi.org/10.1111/j.1365-2494.2011.00828.x

Williams, M. J., Chase, C. C. Jr., \& Hammond, A. C. (2004). Performance of cows and their calves creep-grazed on rhizoma perennial peanut. Agronomy Journal, 96, 671-676. http://dx/doi.org/10.2134/agronj2004.0671

\section{Copyrights}

Copyright for this article is retained by the author(s), with first publication rights granted to the journal.

This is an open-access article distributed under the terms and conditions of the Creative Commons Attribution license (http://creativecommons.org/licenses/by/3.0/). 